\title{
EFFECT OF PANCURONIUM ON INTRAOCULAR PRESSURE CHANGES INDUCED BY SUCCINYLCHOLINE
}

\author{
Halappa N. Konchiger], Yong Eun Lee and Kottarathil Venugopal
}

SEVERAL INVESTIGATORS have reported an increase in intraocular pressure after intravenous administration of succinylcholine in patients undergoing general anaesthesia ${ }^{1-3}$. It has been suggested that such an increase in intraocular pressure may be harmful to patients with glaucoma and penetrating injuries of the eyeball giving rise to possible vitreous expulsion. ${ }^{4-6}$ However, succinylcholine is a valuable muscle relaxant to facilitate tracheal intubation in patients undergoing emergency eye operations. Among various preventative measures, subparalytic doses of d-tubocurarine $(3 \mathrm{mg})$ or gallamine $(20 \mathrm{mg}$ ) before succinylcholine have been shown to prevent the increase in intraocular pressure. ${ }^{1.7 .8}$ Pancuronium has been shown by some investigators to reduce intraocular pressure ${ }^{9,10}$ but studies of the effect of pretreatment with small doses of pancuronium on intraocular changes induced by succinylcholine have produced variable results."

The present study was undertaken to reassess the influence of pretreatment with small doses of pancuronium on intraocular pressure changes associated with the administration of succinylcholine and tracheal intubation.

\section{Materials and Methods}

Thirty patients, aged 18 to 65 (average 39) years and of ASA physical status I and 11 were studied. Patients scheduled to undergo various elective surgical procedures, including intraocular operations, were premedicated with atropine $0.4-0.6 \mathrm{mg}$ and hydroxyzine $50-100 \mathrm{mg}$ approximately 45 minutes before induction of anaesthesia.

Patients were assigned to two groups of 15 patients each by random selection. The control

Halappa N. Konchigeri, M.D., Associate Professor, Yong Eun Lee, M.D., Instructor, Kottarathil Venugopal, M.D., Assistant Professor, Department of Anesthesiology, Abraham Lincoln School of Medicine, University of Illinois Hospitals, 840 South Wood Street, Chicago, Illinois 60612, U.S.A.

Presented in part at a meeting of The International Anesthesia Research Society, March 19-23, 1978, at San Francisco.

Canad. Anaesth. Soc. J., vol. 26, no. 6, November 1979 group (group 1) received saline pretreatment, while patients in the study group (group II) received pancuronium $1 \mathrm{mg}$ intravenously, three minutes before induction of anaesthesia. All patients received intravenous thiopentone $3-5 \mathrm{mg} \cdot \mathrm{kg}^{-1}$ for induction of anaesthesia followed by succinylcholine $1 \mathrm{mg} \cdot \mathrm{kg}^{-1}$ to facilitate the tracheal intubation. Anaesthesia was maintained with 70 per cent nit rous oxide with oxygen. supplemented by Innovar and fentanyl. Patients were kept on controlled ventilation during the study. Intraocular pressure was measured with a Schiotz tonometer at the following times: (1) On arrival in the operating room, when the baseline value was determined after instillation of amethocaine eye drops for topical anaesthesia, (2) one minute after the injection of succinylcholine and (3) one minute after tracheal intubation. All measurements were carried out by one single physician. Results of the study were subjected to statistical analysis using Student's t-test and probability of 5 per cent or less $(\mathrm{p}<0.05)$ was considered significant.

\section{Results}

Results (Table I) showed no significant differences in baseline values of intraocular pressure between the control and test groups. In the control group there was a significant increase in intraocular pressure at one minute after succinylcholine. as well as after tracheal intubation. In the test group there was a mild decrease in intraocular pressure after succinylcholine and a similar increase again after intubation. However, the changes were not significant at both study periods. There was a significant difference in the values of intraocular pressure between the two groups at one minute after succinylcholine as well as after tracheal intubation.

\section{Discussion}

Increase of intraocular pressure following in travenous administration of succinylcholine has been confirmed by several investigators; ${ }^{1-3}$ however, the precise mechanism responsible for this 
TABLE I

Influence of Pretreatment With Pancuronium l/mg on Intraocular Pressure Changes INDUCED By SUCCINYLCHOLINE I $\mathrm{mg} \cdot \mathrm{kg}^{-1}$ AND TRACHEal INTUBation

\begin{tabular}{ccccc}
\hline & & \multicolumn{2}{c}{ Intraocular pressure in kPa (Torr): Mean \pm S.D. } \\
\cline { 3 - 5 } GR & Pre-Treat. & Control & I min after sch & After intubation \\
\hline I & None & $118.0 \pm 10.5$ & $151.9 \pm 19.5$ & $179.7 \pm 19.5$ \\
& & $(15.7 \pm 1.4)$ & $(20.2 \pm 2.6)$ & $(23.9 \pm 2.6)$ \\
II & Pancuronium 1 $\mathrm{mg}$ & $123 \pm 12.0$ & $102.3 \pm 27.8$ & $133.1 \pm 26.3$ \\
& & $(16.4 \pm 1.6)$ & $(13.6 \pm 3.7)$ & $(17.7 \pm 3.5)$ \\
\hline
\end{tabular}

increase of pressure remains unclear. Studies carried out on isolated strips of extraocular muscle have revealed that there are two distinct systems of neuromuscular transmission in extraocular muscle. ${ }^{1.12 .13}$ Based on these observations Katz and Eakins ${ }^{14}$ have concluded that a tonic system composed of large. irregular, poorly defined myofibrils innervated by small diameter $(5 \mu)$ efferent nerves, respond to the action of succinylcholine by contracture, resulting in instant elevation of intraocular pressure. However, the twitch system, which is made up of small, regular. well defined punctate fibrils deriving their nerve supply from large diameter $(12 \mu)$ efferent nerves is completely blocked by the relaxant. The beneficial effect of non-depolarizing muscle relaxants used in pretreatment has been explained by the fact that non-depolarizing muscle relaxants block the stimulating effect of succinylcholine on the tonic system of extraocular muscles. ${ }^{15}$ On the other hand. Adams and Barnett have postulated that the rise in intraocular pressure is a result of transient dilation of choroidal blood vessels induced by succinylcholine.

Several investigators have attempted different measures to prevent the rise in intraocular pressure induced by succinylcholine. Miller, Way and Hickey have advocated pretreating patients with d-tubocurarine or gallamine three minutes before administration of succinylcholine. ${ }^{8}$ Other methods suggested included deep anaesthesia, ${ }^{16}$ slow intravenous infusion of succinylcholine and prior administration of acetazolamide, ${ }^{17}$ but they have met with only partial success.

Our observations in the present study indicate that pancuronium $1.0 \mathrm{mg}$ administered three minutes before succinylcholine can significantly reduce the rise in intraocular pressure. Although tracheal intubation was accompanied by mild elevation of intraocular pressure, the readings were not significantly different from the control values.
Bowen, McGrand and Palmer" found that in their patients pretreatment with pancuronium $1 \mathrm{mg}$ had no significant effect on changes of intraocular pressure induced by succinylcholine. The discrepancy in the results can be explained partly by the differences in methodology, including dosage of drugs administered for induction, the technical procedure used for measurement of intraocular pressure, and intervals between tracheal intubation and measurements.

\section{SUMMARY}

The study was undertaken to evaluate the influence of pretreatment with a small dose of pancuronium on intraocular pressure changes associated with administration of succinylcholine and tracheal intubation. Thirty patients divided into control and study groups were anaesthetized with sodium thiopentone $\left(3-5 \mathrm{mg} \cdot \mathrm{kg}^{-1}\right)$ and intubation with the aid of succinylcholine (1 mg $\mathrm{kg}^{-1}$ ).

The control group received saline pretreatment while the study group received pancuronium I $\mathrm{mg}$ three minutes before succinylcholine. Anaesthesia was maintained with nitrous oxide and oxygen (70:30). A Schiotz tonometer was used to measure intraocular pressure before induction of anaesthesia, one minute after succinylcholine and immediately after intubation.

Patients in the control group demonstrated significant elevation of intracular pressure at one minute after succinylcholine and immediately after intubation, while the study group showed no significant changes at the same observation periods.

These findings indicate that pretreatment with pancuronium $1 \mathrm{mg}$ three minutes before succinylcholine may be beneficial in patients with high intraocular pressure and penetrating injuries of the eye. 


\section{RÉsumé}

L'étude avait pour but d'évaluer l'influence du prè-traitement au pancuronium à petite dose sur les modifications de la tension intraoculaire provoquée parl'administration de succinylcholine et par l'intubation de la trachée. Deux groupes de treize patients, dont un servait ce contrôle, furent anesthésiés avec du thiopental $3-5 \mathrm{mg} \cdot \mathrm{kg}^{-1}$ et

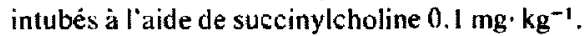

Le groupe de contrôle fut traité avec du soluté physiologique alors que le groupe d'étude reçut pancuronium $1.0 \mathrm{mg}$ trois minutes avant ladministration de succinylcholine. L'anesthesie fut maintenue avec du protoxyde d'azote et d'oxygène (70:30) pendant la période d'étude. Un tonomètre de Schiotz fut employé pour mesurer la pression intraoculaire avant l'induction, une minute après succinylcholine et finalement après l'intubation de la trachée.

Les patients du groupe de contrôle ont montré une élévation significative de la tension intraoculaire une minute après la succinylcholine et immédiatement après l'intubation trachéale, alors que le groupe d'étude r'a pas montré de changements significatifs de tension intraoculaire dans les mèmes périodes d'observation. Ces observations semblent indiquer que le prétraitement au pancuronium I mg trois minute avant l'administration de succinylcholine pourrait être bénéfique aux malades dont la tension intraoculaire est déjà élevée et aux victimes de plaies pénétrantes de l'ceil.

\section{REFERENCES}

1. Dillon, J.B.. Sabawala, P.. Taylor, D.B. \& Gunter, R. Action of succinylcholine on extraocular muscles and Intraocular pressure. Anesthesiology 18: 44 (1957).

2. SCHWARTZ, H. \& DERAETTH, A. Effect of succinylcholine on intraocular pressure in human bejings. Anesthesiology 19: 112 (1958).

3. AdAMS. A.K. \& BarNeTt, K.C. Anaesthesia and intraocular pressure. Anaesthesia $21: 202$ (1966).

4. Wrute, W.D. \& ChURCHILL-DAvidSON, H.C Neuromuscular blocking drugs, in: A Practice of Anaesthesia. 3rd ed.. Chicago. Year Book Medical Publishers. Ine. p. 857 (1972).

5. SOBEL. A.M. Hexafluorenium. succinylcholine and intraocular tension. Anesth. Analg. 4l:399 (1962).

6. Duncalf, D. \& Foldes. F.F. Anesthesia in Ophthalmology. International Ophthalmology Clinics, Boston, Little Brown \& Co., Vol. 32. No. 2.p. 21 (1973).

7. Macri, F.J \& Grimes. P.A. The effect of succinylcholine on the extraocular striate muscles and on the intraocular pressure. Amer. J. Ophthal. 44: 221 (1957).

8. Miller, R.D., WAY, W.L. \& Hickey, R.F. Inhibition of succinylcholine induced increased intraocular pressure by non-depolarizing muscle relaxants. Anesthesiology 29: 123 (1968).

9. SMITh, R.B. \& LENNO, N. Intraocular pressures following pancuronium. Can. Anaesth. Soc. J. 20: 742 (1973).

10. Litwiller, R.W. Difazio. C.A.\& Rushia, E.l.. Pancuronium and intraocular pressure. Anesthesiology 42: 750(1975).

11. Bowen, D.J., McGrand, J.C. \& Palmer, R.J. Intracular pressures after suxamethonium and endotracheal intubation in patients pretreated with pancuronium. B.J. Anesth. 48: 1201 (1976).

12. Lincoff, H.A., Ellis, C.H.. DEVOE, A.G., et al. The effect of Succinylcholine on intraocular pressure. Am. J. Ophthalmology 40: 50 l (1955).

13. Hess. A.\& Pilar, G. Slow fibres in the extraocular muscles of the Cat. J. Physiol (Lond.) 169: 780 (1963).

14. Katz. R.L. \& EAKINS. K.E. The action of neuromuscular blocking agents on extraocular muscle and intraocular pressure. Proc. Roy, Soc. Med. 62: $1217(1969)$.

15. DuncalF. D. \& WeitzNer. S.W. The influence of ventilation and hypercapnia on intraocular pressure during ancsthesia. Anesth. Analg. 42: 232 (1963).

16. Carballo. A.S. Succinylcholine and acetazolamide (Diamox) in anesthesia for ocular surgery. Canad. Anaesth. Soc. J. 12:486(1965). 